\title{
Exploration of the Beta-Actin DNA Integrity Index as Early Genetic Marker of Presence of Breast Cancer
}

\author{
Wafaa Hussien Habeeb ${ }^{1}$, Ahmed AbdulJabbar Suleiman ${ }^{2}$, Haitham Tafash Al-Hitawee ${ }^{3}$
}

${ }^{1}$ Department of Biology, College of Science, University of Anbar, Ramadi, IRAQ

${ }^{2}$ Department of Biotechnology, College of Science, University of Anbar, Ramadi, IRAQ

${ }^{3}$ College of Medicine, University of Falluja, Anbar, IRAQ

*Corresponding Author: Ahmed.suleiman@uoanbar.edu.iq

Citation: Habeeb WH, Suleiman AA, Al-Hitawee HT. Exploration of the Beta-Actin DNA Integrity Index as Early Genetic Marker of Presence of Breast Cancer. Electron J Gen Med. 2020;17(2):em188. https://doi.org/10.29333/ejgm/7618

\section{ARTICLE INFO}

Received: 7 Dec. 2019

Accepted: 30 Dec. 2019

\begin{abstract}
Background: Circulating cell-free DNA (cfDNA) and its integrity index can be a fast and non-invasive (liquid biopsy) biomarker, this provides significant additional data for diagnosis, prognosis and therapy stratification in cancer patient.

Methods: The circulating tumor DNA (ctDNA) concentration and integrity was investigated in the plasma from patients with breast cancer by a quantitative polymerase chain reaction (qPCR) and their diagnostic value for breast cancer etiology was evaluated Plasma samples were collected from 55 patients 40 patients with breast cancer, 5 patients each with other type of cancer (ovarian cancer, colon cancer, stomach cancer) and 20 healthy controls. Real-time PCR of $\beta$-actin gene were investigated using two primer sets ( 400 and $100 \mathrm{bp}$ ) to amplify different DNA fragment lengths. The DNA integrity index was calculated as the ratio of q-PCR results of $\beta$-actin $400 \mathrm{bp} / 100$.
\end{abstract}

Results: In all cancer patients the DNA concentrations were significantly higher $p<0.0001$, than those of the control group. The plasma DNA integrity was statistically significantly lower in breast cancer and colon cancer than the control groups $(\mathrm{p}<0.001)$.

Conclusion: The plasma DNA concentration and integration test can serve as a new diagnostic marker for detection and monitoring of patients with breast cancer and colon cancer.

Keywords: DNA integrity index, $\beta$-actin gene, breast cancer, ctDNA

\section{INTRODUCTION}

Breast cancer is the most prevalent cancer among females that is a significant global health issue. It contributes approximately one-fourth of all cancers and the second prevalent cause of death from cancer in females (1). Every year approximately 458,000 females die from this disease (2). Breast cancer in Iraq is the most dangerous disease with the highest incidence that has threatened women in Iraq over the last 20 years. There are 1000-2000 new cases are recorded every year, $98 \%$ of which influence women and $2 \%$ of which affect males and occupy $14 \%$ of the total disease in varying cancers and 1-6 of every 100,000 women are impacted (3). The risk of breast cancer is also increased by obesity, sedentary lifestyle and alcohol consumption. While the usefulness of mammography in early detection of breast cancer and the subsequent survival benefit have been demonstrated in numerous research, elevated false-positive rates and costs have restricted its application in third world countries. Population awareness and clinical examination of early manifestations of breast cancer remain suggested strategies (4). However, the development of therapeutic methods for breast cancer with the use of adjuvant hormonal treatment, radiotherapy and chemotherapy has led in a continuous decline in mortality from breast cancer over the previous 30 years (5).

The assessment of serum markers as Carcinoembryonic antigen (CEA) or CA15-3 is still used in clinical practice for BC follow-up, but with low sensitivity and specificity $(6,7)$. Blood cancer-derived DNA is a good biomarker for cancer diagnosis. Previous trials have shown a rise in cell-free circulating DNA in various cancer types (8). Mandel and Metais first defined the existence of fragments of cell-free nucleic acids in human blood in 1948 (9). However, there was no proof of their attachment with the disease until 1977 Wang et al. (2003) demonstrated the enhancement of plasma DNA concentration in cancer patient (10). DNA fragments are released into circulation through cell degradation procedures such as apoptosis and necrosis by both healthy and cancer cells. Circulating free relates to DNA fragments produced from cells irrespective of their origin, while fragments explicitly released from cancer cells are primarily referred to as circulating tumor DNA (ctDNA). This biosource may contain mutations, Copy number variations (CNVs) structural variations and modifications in methylation, all of which may provide cell load data and origin of tumor (11). In comparison to programmed cell death in healthy cells, which produces lower and more regular DNA fragments, tumor necrosis triggers DNA release of 
different sizes, DNA integrity Index depicted as a proportion of longer to smaller DNA portions can be clinically helpful for cancer identification as a probable serum biomarker (12). Lately, circulating DNA integrity estimated as the proportion of longer to shorter DNA fragments, It was observed to be higher in gynecologically and breast cancer patients than in healthy people (13).

In the present study, we assess the use and identification of $\beta$-actin repeats and the DNA integrity test in breast cancer patients.

\section{MATERIALS AND METHODS}

\section{Patients}

The study was conducted on 75 women including 40 women with breast cancer at different stages of the disease, 15 among other cancers (ovarian cancer, colon cancer and stomach cancer), five for each type, and 20 normal healthy age matched females. The age ranging between 30 to 88 years were included in this study. All clinical data have been obtained including complete medical history; full clinical examination, type of treatment used and pathological variables. Blood samples were collected from Ramadi Teaching Hospital, Department of Oncology in the period from July 2018 to November 2018 where is the approval of Ethical committee of medical research.

\section{Plasma DNA Preparation}

Samples were separated by centrifugation at $4^{\circ} \mathrm{C}$ for $10 \mathrm{~min}$ at $2000 \times \mathrm{g}$. until use, plasma samples store at $-20^{\circ} \mathrm{C}$.

\section{Extraction of Circulating Tumor DNA}

DNA extraction was done with a Viral Nucleic Acid Extraction Kit II (Geneaid, Canada). Total nucleic acids with the high pure Viral Nucleic Acid Kit (Geneaid). Circulating tumor DNA were were extracted from $1 \mathrm{ml}$ plasma according to guidance from the manufacturer.

\section{Estimation of DNA Concentration}

DNA concentration of samples was measured using Nano drop spectrometer, by putting $1 \mu$ l of the extracted DNA in the instrument to detect concentration and purity by reading the ratio of absorbance at wavelength $260 \backslash 280 \mathrm{~nm}$.

\section{Quantitative PCR of $\beta$-actin Gene}

Quantitative PCR (qPCR) was used to process DNA samples, using SYBR green mastermix. Using two different primary sets for the beta-actin gene, qPCR amplifies the short (100bp) and long (400bp) segments. The sequence of primers, $\beta$-actin (100) $\beta$-actin (400) forward: 5-GCA CCA CAC CTT CTA CAA TGA-3 and $\beta$-actin(100) reverse|: 5-GTC ATC TTC TCG CGG TTG GC-3, $\beta$ actin (400) reverse: 5-TGT CAC GCA CGA TTT CCC-3. The qPCR reaction mixture included $5 \mu \mathrm{l}$ template, $0.25 \mu \mathrm{l}$ uracile DNA glycosylase. $2 \mu \mathrm{l}$ of each primer (forward and reverse), $6.75 \mu \mathrm{l}$ $\mathrm{H} 2 \mathrm{O}$ PCR and $4 \mu \mathrm{l}$ SYBR Green Mastermix. It results in $20 \mu \mathrm{l}$ of

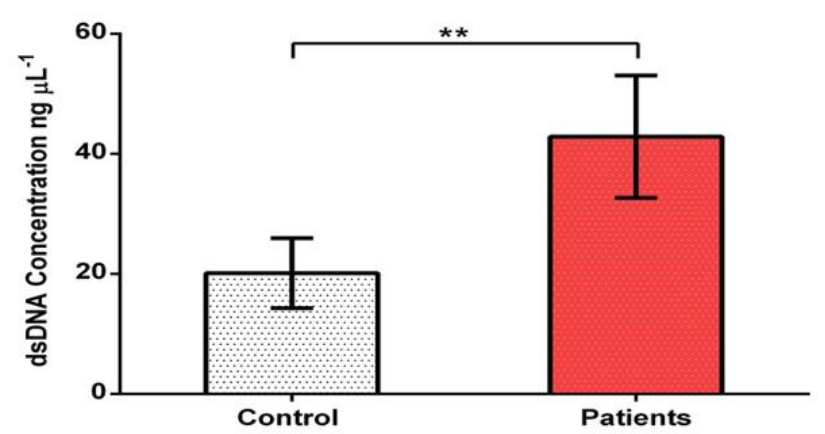

Figure 1. DNA concentration for patient and control

the amount of reaction. The conditions of RT-PCR reactions were pre-denaturation $95 \mathrm{C}$, 3-5 min for 1 cycle, denaturation 95 C, 5-30 sec for 45 cycle, Annealing/Extension/ Detection 5560 C, 5-30 sec for 45 cycle, Melting for 1 cycle. To calculate DNA integrity index by this investigation as the proportion of long DNA fragments (400 bp) to short DNA fragments (100 bp) for every sample.

\section{Statistical Analysis}

A One way analysis of variance ANOVA (Tukey Test) was performed to test whether group variance was significant or not, statistical significance was defined as * $p \leq 0.05$ or ${ }^{\star *} p \leq$ 0.01 . Data were expressed as mean \pm standard deviation and statistical significances were carried out using Graph pad prism version.

\section{RESULTS}

DNA concentration for both patients and control measured by nano drop spectroscopy. The result of control samples were had low concentrations with mean of $20.13 \mathrm{ng} / \mathrm{ul}$, while patients had much higher DNA concentrations in comparison with that of control Figure 1. DNA concentrations extracted from patients have $42.87 \mathrm{ng} / \mathrm{ul}$ as mean. Results shown in Table 1.

To calculate DNA integrity index by this investigation as the ratio of long DNA fragments (400 bp) to short DNA fragments (100 bp) for every sample. the result was found to be higher in $B C$ patients at $p$ value 0.01 and this results was statistical significant when compared with healthy controls group, also showed statistical significant in colon cancer patients at $p$ value 0.5 . Other type of cancer included in this study (ovarian cancer, stomach cancer) showed no significant differences in this investigation as shown in Figure 2.

The mean \pm SD of DNA integrity index for breast cancer women and control and other type of cancer were shown in (Table 2) which were $(3.513 \pm 1.471),(5.759 \pm 0.9938)$ respectively, while in other cancers in this study which include colon cancer, ovarian cancer and stomach cancer were (3.914 $\pm 0.5507),(7.156 \pm 0.9259),(5.640 \pm 1.100)$ respectively. The results showed that the DNA integrity index was highly significant $(P \leq 0.01)$ in breast cancer and colon cancer patients

Table 1. DNA concentration of patients and controls

\begin{tabular}{|c|c|c|c|c|c|}
\hline & NO.Sample & Mean & Std. Deviation & P value & Sig. \\
\hline Patients & 55 & 42.87 & 5.825 & & \\
\hline Control & 20 & 20.13 & 10.20 & 0.0001 & $\star \star$ \\
\hline
\end{tabular}


Table 2. DNA integrity index value $\beta$-actin gene

\begin{tabular}{|c|c|c|c|c|c|}
\hline & Control & Breast cancer & Colon cancer & Ovarian cancer & Stomach cancer \\
\hline Mean & 5.759 & 3.513 & 3.914 & 7.156 & 5.640 \\
\hline SD & 0.9938 & 1.471 & 0.5507 & 0.9259 & 1.100 \\
\hline SE & 0.2222 & 0.2327 & 0.2463 & 0.4141 & 0.4920 \\
\hline Sig & NS & $\star \star$ & * & NS & NS \\
\hline$P$ value & & $<0.0001$ & 0.0173 & 0.0993 & 0.9990 \\
\hline
\end{tabular}

NS= Non-significant, ${ }^{\star \star} p \leq 0.01,{ }^{\star} p \leq 0.05$, Sig= significant, SD=Standard Deviation, $\mathrm{SE}=$ Standard Error

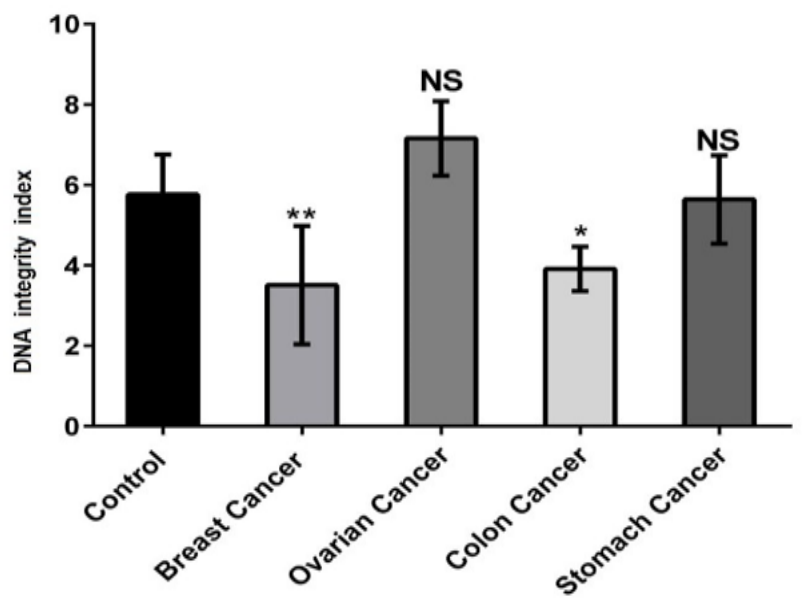

Figure 2. DNA integrity index by $\beta$-actin investigation

compared with healthy control, while there is Non-significant in ovarian cancer and stomach cancer.

\section{DISCUSSION}

Liquid biopsies, unlike present surgical biopsies, are really an attractive and more realistic routine cancer alternative surveillance with ctDNA easily available in cancer patient's plasma, numerous attempts have been made to exploit their clinical usefulness (13). According to the assumption of tumor cells are messier than most normal cell deaths, scientists would expect a greater percentage of fragmented DNA to be found in the cancer group. As the disease advances, an enhanced DNA Integrity Index would be expected to represent the enhanced tumor burden and removing broken DNA, possibly offering a means of not only identifying and diagnosing patients with cancer, but also differentiating on the basis of disease staging and progression (14).

The circulating DNA concentrations of tumors were observed to be higher in patients with cancer than in those with benign diseases and higher in patients with metastatic disease. But, due to technological limitations, at that time, the authors were unable to determine the cellular origin of the tumor DNA. The results of this study agreed with another study (15).

The nucleic acid in the blood can be seen as a positive test of carcinoma. ctDNA in patients with cancer may be caused by cancer cells detached from the mass of the tumor and necrosis or apoptosis (16). The concentration of DNA in cancer patients ranged from zero to microgram amount with an average of 180 $\pm 38 \mathrm{ng} / \mathrm{ml} ; 50 \%$ of the patient's values ranged from 0 to $50 \mathrm{ng}$ $/ \mathrm{ml}$ and the other $50 \%$ ranged from 50 to $5000 \mathrm{ng} / \mathrm{ml}$ (17). It is now evident that the concentration of DNA in cancer patients is much higher than the concentration of DNA in normal cells with high statistical confidence. However, this DNA must be further studied in order to link this DNA to cancer cells, which is why specific DNA integrity index have been studied in this study.

Traditionally, $\beta$-actin (ACTB) was considered one of endogenous housekeeping gene and was commonly used to measure tumor expression concentrations as a reference gene/protein. ACTB is strongly correlated with a multitude of cancers, however, and cumulating proof shows that ACTB is deregulated in melanoma, liver, kidney, gastric, colorectal, esophageal, lymphoma, prostate, pancreatic, lung, ovarian, breast, and leukemia. In most tumor cells and tissues, ACTB is usually discovered to be up-regulated. The aberrant polymerization and expression of ACTB and the resulting modifications to the cytoskeleton was shown to be consistent with metastasis and invasive cancer (18).

Our results showed that there was a higher statistical significant for DNA integrity index in breast cancer patient compared to control group. No previous study was found in this regard but there are similar studies on other types of cancers. Also the result showed there is statistical significant in the patient with colon cancer but there is no significant in ovarian cancer and stomach cancer.

The study of Sun et al. (21) to estimate the role of plasma CtDNA in estimating the response of preoperative chemotherapy in rectal cancer patients, two fragment of betaactin gene were used (400/100-bp), result of this study cleared that the concentration of 400-base pair (bp) DNA, the DNA proportion of 400-/100-bp significantly decreased in the group with good response after chemo-radiotherapy. In cancer patients, levels of both 100-bp $(p<0.01)$ and 400-bp $(p<0.01)$ segment DNA were significantly higher than in healthy controls. The ratio of concentrations of $400-/ 100-b p$ DNA showing integrity of circulating plasma DNA was significantly higher in cancer patients than in healthy controls $(p<0.05)$. Therefore, circulating DNA detection in rectal cancer patients may be helpful in assessing the impact preoperative chemoradiotherapy (19).

Previous studies showed different sizes of tumor DNA from cancers, while non-tumor apoptotic cells were equally truncated into pieces and shorter than $200 \mathrm{bp}$. Fragments of cell-free DNA from necrosis of cancer are varying in size and usually more than $200 \mathrm{bp}$. Furthermore, the ratio of longer fragments to smaller fragments, known as the integrity index, was more accurate in the reflection of tumor status (20).

\section{CONCLUSION}

The main conclusion of this work is the DNA integrity index of $\beta$-actin can be serve as early diagnostic tools of breast cancer and may be other type of cancer also the concentration of DNA in plasma differ in cancer patients in compared with control group. 


\section{ACKNOWLEDGEMENTS}

Authors would like to express great thanks for my university (University of Anbar), my faculty (Faculty of Sciences), as well as my Department (Biology Department) for providing equipment and materials to complete this work.

\section{REFERENCES}

1. Abdulrahman GO, Rahman GA. Epidemiology of breast cancer in Europe and Africa. Journal of Cancer Epidemiology. 2012;2012:915610. https://doi.org/10.1155/ 2012/915610 PMid:22693503 PMCid:PMC3368191

2. Jemal A, Bray F, Center, MM, Ferlay J, Ward E, Forman D. Global cancer statistics. CA: A Cancer Journal for Clinicians. 2011;61(2):69-90. https://doi.org/10.3322/caac.20107 PMid:21296855

3. Bosetti C, Bertuccio P, Levi F, Chatenoud L, Negri E, La Vecchia C. The decline in breast cancer mortality in Europe: an update (to 2009). The Breast. 2012;21(1):77-82. https://doi.org/10.1016/j.breast.2011.08.001 PMid:21906943

4. Torre LA, Bray F, Siegel RL, Ferlay J, Lortet - Tieulent J, Jemal A. Global cancer statistics, 2012. CA: A Cancer Journal for Clinicians. 2015;65(2):87-108. https://doi.org/ 10.3322/caac.21262 PMid:25651787

5. Duffy MJ, Evoy D, McDermott EW. CA 15-3: uses and limitation as a biomarker for breast cancer. Clinica Chimica Acta. 2010;411(23-24):1869-74. https://doi.org/10.1016/ j.cca.2010.08.039 PMid:20816948

6. El-Gayar D, El-Abd N, Hassan N, Ali R. Increased free circulating DNA integrity index as a serum biomarker in patients with colorectal carcinoma. Asian Pac J Cancer Prev. 2016;17(3):939-44. https://doi.org/10.7314/ APJCP.2016.17.3.939 PMid:27039817

7. Wang BG, Huang HY, Chen YC, Bristow RE, Kassauei K, Cheng CC, ... Shih IM. Increased plasma DNA integrity in cancer patients. Cancer Research. 2003;63(14):3966-8.

8. Mandel P, Metais P. Circulating nucleic acid. Acad Sci Paris. 1948;142:241-3.

9. McPherson K, Steel C, Dixon JM. ABC of breast diseases: breast cancer-epidemiology, risk factors, and genetics. BMJ: British Medical Journal. 2000;321(7261):624. https://doi.org/10.1136/bmj.321.7261.624 PMid:10977847 PMCid:PMC1118507

10. Reinert T, Schøler LV, Thomsen R, Tobiasen H, Vang S, Norden toft I, ... Hamilton-Dutoit S. Analysis of circulating tumour DNA to monitor disease burden following colorectal cancer surgery. Gut. 2016;65(4):625-34. https://doi.org/10.1136/gutjnl-2014-308859 PMid:25654990
11. Umetani N, Giuliano AE, Hiramatsu SH, Amersi F, Nakagawa T, Martino S, Hoon DS. Prediction of breast tumor progression by integrity of free circulating DNA in serum. Journal of Clinical Oncology. 2006;24(26):4270-6. https://doi.org/10.1200/JCO.2006.05.9493 PMid:16963729

12. Salvianti F, Giuliani C, Petrone L, Mancini I, Vezzosi V, Pupilli C, Pinzani P. Integrity and quantity of total cell-free DNA in the diagnosis of thyroid cancer: Correlation with cytological classification. International Journal of Molecular Sciences. 2017;18(7):1350. https://doi.org/ 10.3390/ijms18071350 PMid:28672797 PMCid:PMC5535843

13. Reinert T, Schøler LV, Thomsen R, Tobiasen H, Vang S, Nordentoft I, ... Hamilton-Dutoit S. Analysis of circulating tumour DNA to monitor disease burden following colorectal cancer surgery. Gut. (2016);65(4):625-34. https://doi.org/10.1136/gutjnl-2014-308859 PMid:25654990

14. Shao Y, Sun X, He Y, Liu C, Liu H. Elevated levels of serum tumor markers CEA and CA15-3 are prognostic parameters for different molecular subtypes of breast cancer. PloS One. 2015;10(7):e0133830. https://doi.org/10.1371/journal. pone.0133830 PMid:26207909 PMCid:PMC4514648

15. Chudasama DY, Aladag Z, Felicien MI, Hall M, Beeson J, Asadi N, ... Anikin, VB. Prognostic value of the DNA integrity index in patients with malignant lung tumors. Oncotarget. 2018;9(30):21281-8. https://doi.org/10.18632/oncotarget. 25086 PMid:29765538 PMCid:PMC5940399

16. Sidransky D, Von Eschenbach A, Tsai YC, Jones $P$, Summerhayes I, Marshall F, ... Frost P. Identification of p53 gene mutations in bladder cancers and urine samples. Science. 1991;252(5006):706-9. https://doi.org/10.1126/ science.2024123 PMid:2024123

17. Jahr S, Hentze H, Englisch S, Hardt D, Fackelmayer F O, Hesch R D, Knippers R. DNA fragments in the blood plasma of cancer patients: quantitations and evidence for their origin from apoptotic and necrotic cells. Cancer Research. 2001;61(4):1659-65.

18. Leon SA, Shapiro B, Sklaroff DM, Yaros MJ. Free DNA in the serum of cancer patients and the effect of therapy. Cancer Research. 1977;37(3):646-50.

19. Guo C. Liu S. Wang J, Sun MZ, Greenaway FT. ACTB in cancer. Clinica Chimica Acta. 2013;417(8):39-44. https://doi.org/10.1016/j.cca.2012.12.012 PMid:23266771

20. Agostini M, Pucciarelli S, Enzo MV, Del Bianco P, Briarava M, Bedin C, ... Toppan P. Circulating cell-free DNA: a promising marker of pathologic tumor response in rectal cancer patients receiving preoperative chemoradiotherapy. Annals of Surgical Oncology. 2011;18(9):2461-8. https://doi.org/10.1245/s10434-011-1638-y PMid:21416156

21. Sun W, Sun Y, Zhu M, Wang Z, Zhang H, Xin Y, ... Liu Y. The role of plasma cell-free DNA detection in predicting preoperative chemoradiotherapy response in rectal cancer patients. Oncology Reports. 2014;31(3):1466-72. https://doi.org/10.3892/or.2013.2949 PMid:24378613 